\author{
Afroze Nazneen, \\ College of Business, University of Jeddah, Saudi Arabia \\ (iD) ORCID ID 0000-0003-0843-1000 \\ email: anazneen@uj.edu.sa \\ Tagreed Alsulimani, \\ University of Jeddah, Saudi Arabia \\ email: tsalsilimani@uj.edu.sa \\ (D) ORCID ID 0000-0003-0676-4338. \\ Rohan Sharma, \\ St Soldier Institute of Business Management \& Agriculture, India \\ D ORCID ID 0000-0001-9053-6842 \\ email: rohansharma001@gmail.com \\ Correspondence author: anazneen@uj.edu.sa
}

\title{
MARKETING AND MANAGEMENT IN HIGHER EDUCATION: THE RELATIONSHIP BETWEEN THE QUALITY OF ONLINE PROGRAMMES AND STUDENTS' SATISFACTION
}

Abstract. Presently online courses have been a big agenda in educational institutes apart from their academic hours and to engage students more in their studies apart from their involvement in academic hours. The purpose of this study is how the online program quality can be improved from both business point of view as well as for the understanding of student's expectation from an online program irrespective of one's interest. In this study, researchers tried to analyse the relationship among various factors involved leading to student satisfaction which become the source of successful online programs. This study applied SEM on smart PLS to analyse a survey of 100 respondents and found that Online program quality Perception is the multifaceted dimension, and it also involves quality instructors who also seen as a significant construct. Based on the literature review and discussions presented the theoretical framework for online learning program course quality was developed. Findings indicate that high student satisfaction is relatively associated with the user-friendly interface, which eases the students to further continue with the course. Along with these quality instructors also contribute much to student satisfaction. Content of course, although assumed to be essential along with the online discussion on forums it was found not significant, which is a surprise and unexpected finding. Based on calculations and modelling estimates, the model is in the best fit. The results show in the form of external loadings of every construct, which is given below explains the variance of respective latent constructs. It was also found that factors are contributing to perceived online programme effectiveness which are Course Content, Online Assignments, Interaction with Peers, Quality Instructors and User Interface respectively.

Keywords: online program, student satisfaction, MOOCS, programme effectiveness, quality instructors, higher education.

Introduction. In the era of globalisation and fast-changing technology, education is no more border oriented, and it has witnessed that anybody at any age can avail knowledge in the world of the network where free knowledge is available anywhere at any time. Online learning program offering institutions face unique challenges around the world due to competitive digital environments. The online learning programs which are being offered are student favouring rather than the profit-oriented. Now the focus is on studentoriented marketing. Nowadays in India, IIT is offering online programs in the form of Massive Open Online Course (MOOC) typically offered for free to those outside of the institution's student body. Moreover, institutions have to provide a new way to retain their students.

Cite as: Nazneen, A., Alsulimani, T., \& Sharma, R. (2020). Marketing and Management in Higher Education: the Relationship between the Quality of Online Programmes and Student's Satisfaction. Marketing and Management of Innovations, 2, 235-246. http://doi.org/10.21272/mmi.2020.2-17 
A., Nazneen, T., Alsulimani, R., Sharma. Marketing and Management in Higher Education: the Relationship between the Quality of Online Programmes and Student's Satisfaction.

An online course is defined as one in which at least $80 \%$ of the course content is delivered online. An online student on the other side of the globe can have the same level of access and ability to participate as one in the next room. In higher education, online courses are becoming an integral part due to availability of internet resources (Li \& Irby, 2008; Luyt, 2013; Lyons, 2004). Online education will be critical for the future of higher education (Allen \& Seaman, 2014). Online courses provide a great extent of flexibility and autonomy for the students. Attitude and perception of the student are essential for consideration as students with higher levels of self-directed learning are more successful in online settings (Lin \& Hsieh, 2001). In the competitive market, branding is a valuable and intangible asset of a company and plays a vital role because positive brands will enable their customers to visualise better and understand products and services that are being offered to them. (Lee et al., 2008). Institutions were establishing marketing strategies which promote brand image among students for enhancing their in-job sector (as Upgrade advertisement) and seeking the loyalty of students and promoting performance.

Although there is a particular organisation which checks the quality of online programs, still much work needs to be done. There is the paucity of research work in this field. Further, no studies investigate how the various factors play a significant role in impacting the attitudes and behaviours of the students who belong to the agricultural state of Punjab.

Literature Review. The objective of this study to examine the various aspects of online learning programs which leads ultimately to student's satisfaction which is perceived by him /her while enrolling into the program at various platforms. The researcher reviewed the literature according to the factors which could play an important role. Based on this intention the review has been divided accordingly

Various researchers addressed that competency and technical skills are required for preparing and delivering the content (McLoughlin, Brady, Lee, \& Russell, 2007; Ensher, Heun, \& Blanchard, 2003). Moreover, instructors must recognise the student's needs and provide the course content in a crisp, clear and concise manner (CHEA, 2002; Greenagel, 2002; Kituyi \& Tusubira, 2013).

Bouilheres et al. (2020) conducted a study to explore the benefits of blended learning towards students learning experiences using 66 students enrolled in 8 different blended learning courses and found that the students' perception of their learning experiences at the university was beneficially impacted as a result of the blended learning environment in each of their classes and the contributory dimension identified were Engagement, Flexibility of Learning, Online learning experience and self-confidence. Kintu, J. M., Zhu, C. and Kagambe, E (2017) conducted a study on 238 students to investigate the effectiveness of blended learning environment through analysing the relationship between students characteristics/background, design features and learning outcomes and found that some of the students' characteristics/backgrounds and design features are significant predictors for students learning outcomes in blended learning.

Puzziferro and Shelton (2014) suggest that to provide quality content with many things has to be taken into consideration and to give proper shape to the course content. It has to undergo various processes from selecting and designs course material as per the academic requirement with the help of the subject expert for attaining the course objectives. The plethora of literature is available on the discussion of online curriculum development (Chao et al., 2010; Diamond, 2011; Moallem, 2003; Reeves, Herrington \& Oliver, 2004; Vooggt et al., 2015; Xu \& Morris, 2007).

Hrastinski (2009): Online learning involves Visualisations, listening or observing, which is a kind of active learning tools which supports the student is to engage with the content, though entirely, and reflection. Video contents are prepared intuitively and conceptually according to the student's ability to understand and learn. To connect the students, appropriate content like images, videos are being developed by keeping in mind the problems and issues being faced by students at par and effective and impactful visualisations impart vital role in it.

Fife (2018): Authentic assignments play a vital role in assessing learning outcomes. Various online programs especially MOOCs gradually become part of credit-bearing programs of individual institutes 
A., Nazneen, T., Alsulimani, R., Sharma. Marketing and Management in Higher Education: the Relationship between the Quality of Online Programmes and Student's Satisfaction.

which further are being recognised by job providers. Such online programs strongly focus on designing learning tasks in the form of assignments to support the development at every step which is also an essential part of assessment and procedure of judging the progress of learner (Boud, 1995). The nature of assessment has shifted to the «improved learning» and the recognition "effective learning». Selfassessment is also being undertaken to identify their competencies and to meet the learning goals.

Smaldino and Yamagata-Lynch (2015) suggest that usually, interfaces are being developed from the faculty point of view. Struggling with the use of technology may distract learners, teachers and which may later impact severely on learning. Teachers, Students and stakeholder play a significant role in online programs (Wagner et al.,2008) so to facilitate the services technology sophistication is the utmost requirement as per user needs. Various researchers proposed and designed prototype by staying focused on the architecture of user interface (Farhan et al., 2019) later, which plays a vital role among the main parties participating on an online education platform. Fein and Logan (2003) recommended Frequently Asked Questions as a solution to provide answers to students immediately for their recurring queries which serves a smart way to provide an easy way to make students familiar with interface or the system.

Researchers always gave importance to social space for interaction (Tinto,1999) which is the utmost requirement in online education. Shu H. and Gu X. (2018) administered a study using 604 dialogues and 5090 posts to identify the differences of group interactions in blended learning groups and face to face interaction. They found a strong group controlling pattern in the Online learning component, whereas an individual controlling pattern was found in the face to face mode. The dialogue clusters of students were more substantial when the interactions focused on their real lives and were related to the subject of the course but also found that the interaction in the classroom was more in-depth than that in the Online learning mode. Bandura (2007) said it is proven from the social cognition theories that interaction among students and faculty fundamentally influences them. The interaction also improves the learning behaviour and motivate the students to complete the course. Researchers always gave importance to social space for interaction which is the utmost requirement in online education. Interaction processes in e-learning systems promote active learning (Beyth-Marom et al., 2005).

Hew et al. (2011) focused on effective communication in online discussions within large classes is the mandate to engage in dialogue and help students communicate more effectively, facilitate their learning process, and improve their learning. There is the facility of discussion forums, online chats as the provision of permanent space to learners for interaction and resolution of problems. Researchers recognised various factors responsible for the non-participation of learners on discussions front. Limani et all (2019) recognised technology as a critical tool in higher education institutes to transform the learning and for effective communication among students and teachers and focused on the implementation of digital technology to enhance the teaching and learning.

Student Satisfaction is directly related to the meeting perception of students. Various studies have proved that satisfaction is meeting the requirement of the users (Lucas, 1978; Robey, 1979; Ives, Olson and Baroudi, 2008): Student Satisfaction is directly related with the meeting perception of students. Various studies have proved that satisfaction is meeting the requirement of the users. Zhang et al. (2006) recognised student satisfaction directly linked with interactivity in the online platform.

Relationship between Perceived online Learning Program Quality and Student Satisfaction: On online programs literature, several studies have established the relationship between the quality of online programs offered and student satisfaction. The relationships have been investigated by many researchers (Delone \& McLean, 2003; Shi, 2010; Lee, 2010; Xu, Huang, Wang, and Heales, 2014).

A study conducted by $(\mathrm{Teo}, 2010)$ on students attending online course programs found that perceived course quality positively affects student satisfaction. This finding was further supported by Chiu et al. (2005), in a study of student satisfaction at various online portals; they confirmed that the service quality has a positive relationship with student satisfaction. 
A., Nazneen, T., Alsulimani, R., Sharma. Marketing and Management in Higher Education: the Relationship between the Quality of Online Programmes and Student's Satisfaction.

Researchers Dabbagh \& Kitsantas, 2012; McLoughlin \& Lee, 2010; Zhai et al.,2017, analysed the relationship between content quality and student satisfaction using structural equation modelling among students and found that the perceived course quality is positively related to student satisfaction. The relationship between information quality and student satisfaction is supported by many empirical studies (Bhatti, Bouch and Kuchinsky, 2000). Thus, there is a secure link between perceived course quality and student satisfaction in online learning programs. Al-Rahmi et al. (2018) conducted a study on Malaysian university students. They found that the content of e-learning and self-efficacy has a positive impact and substantially associated with perceived usefulness and student's satisfaction which impact university student's intention to utilise e-learning. They further found that university students in Malaysia have positive perception towards e-learning and intend to practice it for educational purposes.

Methodology and research methods. Theoretical Framework. Based on the literature review and discussions presented above, the following theoretical framework for online learning program course quality was developed. Figure 1 shows the course quality antecedents, namely, Course Content, Online Assignments, User interface, interaction with peers, quality instructors, perceived online learning Program course quality, and student satisfaction constructs. All the constructs have been briefly explained in the above section.

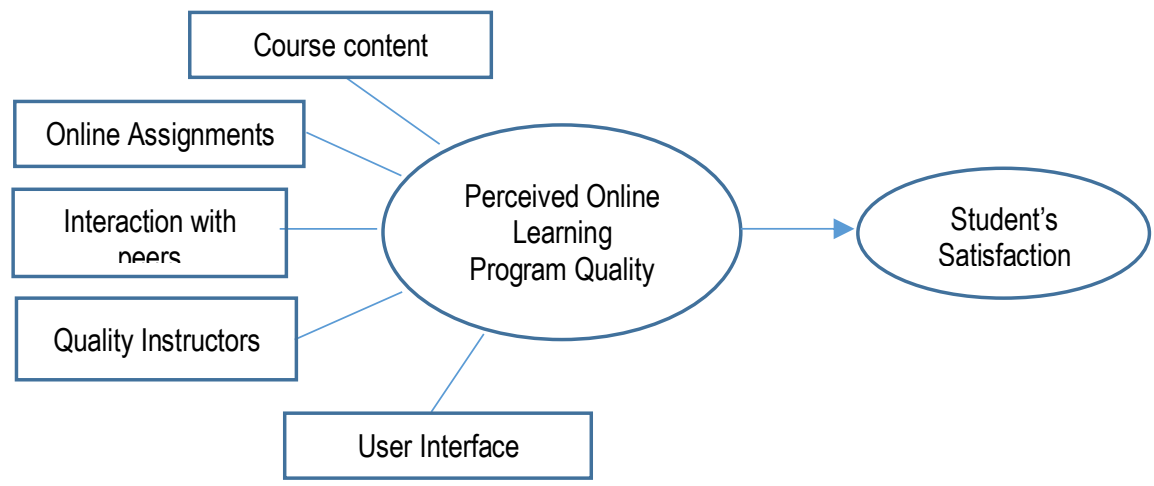

Source: developed by the authors.

Figure 1. The course quality antecedents

Hypotheses. Prior discussion has led to a brief examination of the existing literature review, and the resultant research gaps led to the development of the hypotheses in this research. The six hypotheses are:

H1: Course Content is positively related to perceived online learning program quality.

$\mathrm{H} 2$ : Online Assignments is positively related to perceived online learning program quality.

$\mathrm{H} 3$ : User Interface is positively related to perceived online learning program quality.

$\mathrm{H} 4$ : Interaction with Peers is positively related to perceived online learning program quality.

$\mathrm{H} 5$ : Instructor Quality is positively related to student satisfaction.

H6: Perceived online learning program quality is positively related to student satisfaction.

The researcher has adapted items on 5 points Likert scale from previously validated scales to assess the proposed model and was modified to measure the specific constructs in this study. The constructs in the questionnaire were direct, simple and short sentences to fit the students as the respondents in this study. Most of the statements rephrased to fit the online course student perception and quality of online contents which are being studied. To establish support for face validity experts reviewed the constructs and the initial set of measure items. Based on their suggestions, a few of the items were rephrased, but 
A., Nazneen, T., Alsulimani, R., Sharma. Marketing and Management in Higher Education: the Relationship between the Quality of Online Programmes and Student's Satisfaction.

no item was deleted. All constructs were reflective since the items reflect the meaning of the constructs. Reflective indicators mean they measure the same underlying phenomenon. To test the research model, the questionnaire has 49 statements which later grouped under six latent constructs (see Figure 1).

Sample. The respondents are students who had taken up online courses. The population for this study comprised of students of engineering institutes. Purposive convenience sampling methods were used. The general rule for the minimum number of respondents or sample size is the ten-to-one ratio of the number of independent variables to be tested as suggested by Hair et al. (1998). Since there are 6 independent latent constructs in this study, a minimum sample size of 100 respondents would be appropriate.

The survey questionnaire was distributed to the respondents during the working day by the researchers. The potential respondents were first filtered by asking them a few questions with regards to their enrollment and experience with the online program before they were given the set of the survey questionnaire. Confidentiality was ensured as the subjects were not required to state their names or other particulars on the survey form.

Table 1. Respondents' Profile.

\begin{tabular}{ccc}
\hline Demographic & Variable Categories & Frequency \\
\hline Gender & Male & 62 \\
& Female & 38 \\
Age & 20 Years or Below & 17 \\
& $21-30$ Years & 62 \\
& $31-40$ Years & 18 \\
Academics Major & Above 40 Years & 3 \\
& Engineering & 65 \\
Qualification & Management & 35 \\
& 12th or Diploma & 17 \\
& Graduation & 64 \\
& Post Graduation & 16 \\
& Doctoral & 3 \\
\hline
\end{tabular}

Source: developed by the authors

Results. The current study used Smart PLS 3 evaluate 6 underlying constructs on 49 statements through factor analysis and Smart PLS (Ringle, Wende \& Will, 2005) partial least square structural equation modelling (PLS-SEM) tool to evaluate how the constructs presented in Figure 1 might relate to each other. Factor analysis is a technique that is used to reduce a large number of variables into a fewer number of factors. This technique extracts maximum common variance from all variables and put them into an average score. KMO and Bartlett's test was conducted to measure the sampling adequacy and to find the correlation matrix as an identity matrix. Communalities show how much of the variance, the value which is more than $50 \%$ to be considered for further analysis in the variables.

In the Total Variance Explained Table 2, 5 factors have been extracted, which accounts for almost $88 \%$ of the variance while remaining factors are not significant. The 5 factors contributing to perceived online contributing, which are as follows:

Factor 1: Course Content.

Factor 2: Online Assignments.

Factor 3: Interaction with Peers.

Factor 4: Quality Instructors.

Factor 5: User Interface. 
A., Nazneen, T., Alsulimani, R., Sharma. Marketing and Management in Higher Education: the Relationship between the Quality of Online Programmes and Student's Satisfaction.

\begin{tabular}{cc}
\hline Table 2. Showing Total Variance Explained & \\
\hline Factors & Cumulative \% \\
\hline 1- Course Content & 61.857 \\
2- Online Assignments & 75.819 \\
3- Interaction with Peers & 80.445 \\
4- Quality Instructors & 84.285 \\
5- User Interface & 88.103 \\
\hline
\end{tabular}

Source: developed by the authors.

The nomenclature of these factors has done as per the nature of the statements depicting their resembling behaviour. The PLS-SEM technique is a statistical method that has been developed for the analysis of latent variable structural models involving multiple constructs with multiple indicators. PLSSEMs have several potential strengths, including the ability for the testing of the psychometric properties of the scales used to measure a variable, as well as the strength and the direction of relationships among the variables (Akter et al., 2011). The PLS-SEM consisted of two sets of testing equations: first - the assessment of the measurement model, and the second - the assessment of the structural model (Hair, Ringle \& Sarstedt, 2011). The measurement model which is the process of calculating the item reliability and validity; and the structural model which is the method of determining the appropriate nature of the relationships (paths) between the measures and constructs (Hair et al., 1998). The estimated path coefficients indicate the sign and the power of the relationships while loadings indicate the strength of the measures (Hair et al., 2011). The confirmatory factor analysis was first conducted to assess the measurement model; then, the structural relationships were examined (Anderson \& Gerbing, 1988; Hair et al., 1998). The two main criteria used for testing the measurement model are reliability or internal consistency and validity. The reliability of a research instrument concerns the extent to which the instrument produces consistent results in repeated measurements, whereas validity is the degree to which how well a test is developed and measures what is supposed to measure (Sekaran \& Bougie, 2010). To validate this measurement model, two basic approaches to validity were assessed: convergent validity and discriminant validity. To analyse the reliability/internal consistency of the items, the researcher used Cronbach's alpha coefficient and composite reliability (CR) value. Table 3 shows that all Cronbach's alpha values are above 0.6 cutoff values, as suggested by Thorndike (1995). Another way to determine internal consistency is by looking at composite reliability values. The composite reliability (CR) values also ranged from 0.967 to 0.984 (Table 2). According to Fornell and Larcker (1981), a composite reliability value of 0.70 or higher is considered acceptable and hence concluded that the measurement model was reliable.

Table 3. Showing Composite Reliability \& Average Variance Extracted (AVE)

\begin{tabular}{ccc}
\hline Constructs & Composite Reliability & AVE \\
\hline Course Content & 0.972 & 0.814 \\
Interaction with Peers & 0.981 & 0.828 \\
Online Assignments & 0.979 & 0.904 \\
Quality Instructors & 0.976 & 0.892 \\
Student Satisfaction & 0.984 & 0.911 \\
User Interface & 0.967 & 0.881 \\
\hline
\end{tabular}

Source: developed by the authors.

Convergent validity is used to measure the individual construct. The first step in the measurement model is being tested for convergent validity which is the extent to which multiple items to measure the same concept agree (MacKinnon, 2008). Anderson and Gerbing (1988) stated that convergent validity is established if all factor loadings for the items measuring the same construct are statistically significant. 
A., Nazneen, T., Alsulimani, R., Sharma. Marketing and Management in Higher Education: the Relationship between the Quality of Online Programmes and Student's Satisfaction.

According to Hair et al. (1998), convergent validity could be accessed through factor loadings, composite reliability and the average variance extracted. The results of the measurement model (Table 3 ) show that the loadings for all items exceeded the recommended value of 0.5 (Hair et al., 1998). All values of the average variance extracted (AVE) which measures the variance captured by the indicators relative to measurement error were more significant than 0.50 to indicate the acceptability of the constructs (Fornell \& Larcker, 1981; Henseler, Ringle, \& Sinkovics, 2009). AVE values ranged from 0.814 to 0.911 , which exceeded the recommended value of 0.50 . Table 3 indicates that these indicators satisfied the convergent validity of the constructs. According to the researcher Fornell and Larcker (1981), the square root of AVE in each latent variable can be used to establish discriminant validity if this value is more significant than other correlation values among the latent variables. Table 4 showing the square root of AVE across the constructs, which are shown diagonally. Table 4 shows that discriminant validity is well established.

Table 4. Showing Fornell-Larcker Criterion Analysis to Check Discriminant Validity

\begin{tabular}{|c|c|c|c|c|c|c|}
\hline-[ & $\begin{array}{l}\text { Course } \\
\text { Content }\end{array}$ & $\begin{array}{l}\text { Interaction } \\
\text { with Peers }\end{array}$ & $\begin{array}{c}\text { Online } \\
\text { Assignments }\end{array}$ & $\begin{array}{c}\text { Quality } \\
\text { Instructors }\end{array}$ & $\begin{array}{c}\text { Student } \\
\text { Satisfaction }\end{array}$ & $\begin{array}{c}\text { User } \\
\text { Interface }\end{array}$ \\
\hline Course Content & 0.902 & & & & & \\
\hline Interaction with Peers & 0.968 & 0.910 & & & & \\
\hline Online Assignments & 0.927 & 0.958 & 0.951 & & & \\
\hline Quality Instructors & 0.957 & 0.984 & 0.950 & 0.944 & & \\
\hline Student Satisfaction & 0.955 & 0.955 & 0.943 & 0.941 & 0.955 & \\
\hline User Interface & 0.971 & 0.946 & 0.919 & 0.925 & 0.976 & 0.938 \\
\hline
\end{tabular}

Source: developed by the authors.

SRMR (Standardised Root Mean Square Residual) is an absolute measure of fit found .070 in Table 4, which is less than 08 is generally considered a good fit (Hu \& Bentler, 1999).

Table 5. Showing Standardised Root Mean Square Residual (SRMR)

\begin{tabular}{ll}
\hline Model Fitness & \\
\hline & Saturated Model \\
SRMR & 0.070 \\
\hline
\end{tabular}

Source: developed by the authors.

Path Coefficients are estimated from correlations, and It indicates how well all independent variable explains. As per Figure 2, it is very communicated about how much of the variance is being explained by the respective constructs.

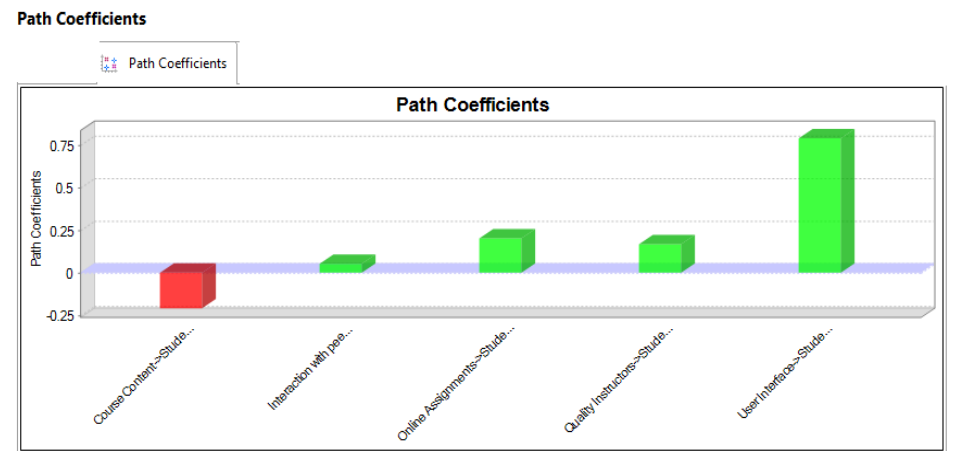

Figure 2. Path Coefficient

Source: developed by the authors. 
A., Nazneen, T., Alsulimani, R., Sharma. Marketing and Management in Higher Education: the Relationship between the Quality of Online Programmes and Student's Satisfaction.

Table 6. Showing Hypotheses Testing

\begin{tabular}{ccc}
\hline Hypothesis & Path Coefficient & Hypothesis \\
\hline H1: Course Content is positively related to perceived online learning \\
$\begin{array}{c}\text { program quality. } \\
\text { H2: Online Assignments is positively related to perceived online } \\
\text { learning program quality. }\end{array}$ & -0.209 & Not Accepted \\
$\begin{array}{c}\text { H3: User Interface is positively related to perceived online learning } \\
\text { program quality. }\end{array}$ & 0.053 & Accepted \\
$\begin{array}{c}\text { Iearning program quality. } \\
\text { H4: Interaction with Peer is positively related to perceived online }\end{array}$ & 0.167 & Accepted \\
$\begin{array}{c}\text { H5: Instructor Quality is positively related to student satisfaction. } \\
\text { H6: Perceived online learning program quality is positively related to } \\
\text { student satisfaction. }\end{array}$ & 0.789 & Accepted \\
\hline
\end{tabular}

Source: developed by the authors.

Hypotheses Testing. All of the hypotheses, except two are accepted as per mentioned in Table 7.

Table 7. Showing Summary of Hypotheses Testing

\begin{tabular}{cc} 
Hypothesis & $\begin{array}{c}\text { Accepted? } \\
\text { (Yes/no) }\end{array}$ \\
\hline H1: Course Content is positively related to perceived online learning program quality. & No \\
H2: Online Assignments is positively related to perceived online learning program quality. & Yes \\
H3: User Interface is positively related to perceived online learning program quality. & Yes \\
H4: Interaction with Peers is positively related to perceived online learning program quality. & No \\
H5: Instructor Quality is positively related to student satisfaction. & Yes \\
H6: Perceived online learning program quality is positively related to student satisfaction. & Yes \\
\hline
\end{tabular}

Source: developed by the authors.

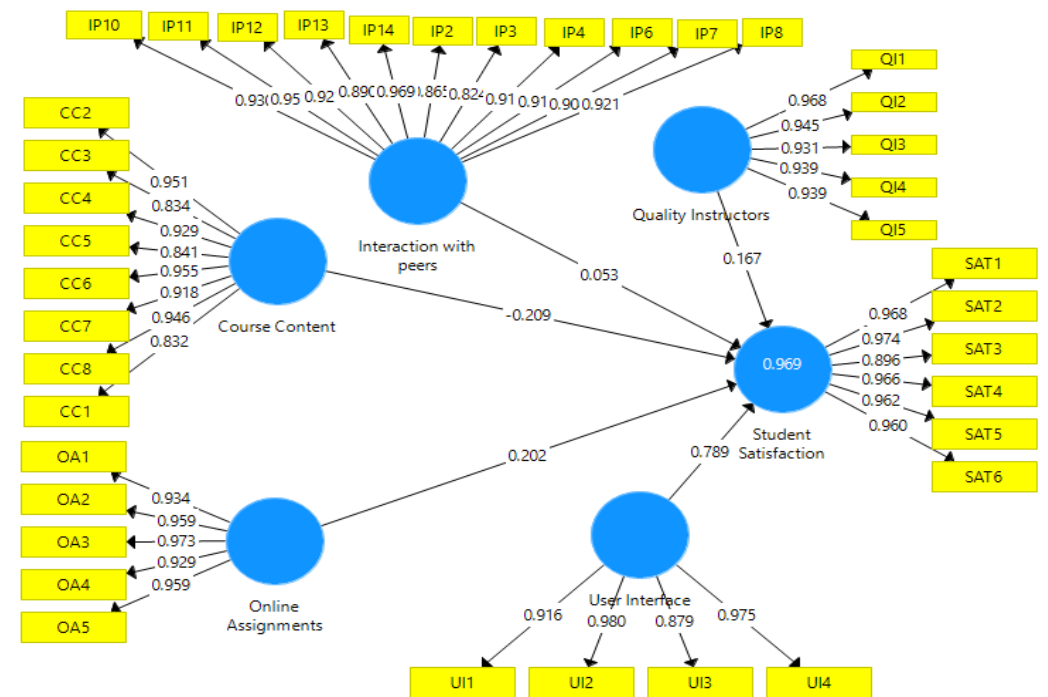

Figure 3. PLS Path Model Estimation and output generated by calculation on running the PLSSEM algorithm.

Source: developed by the authors. 
A., Nazneen, T., Alsulimani, R., Sharma. Marketing and Management in Higher Education: the Relationship between the Quality of Online Programmes and Student's Satisfaction.

Based on calculations and modelling estimates, the model is in the best fit. The results show in the form of external loadings of every construct, which is given below explains the variance of respective latent constructs. The outer loadings and average variance extracted (AVE) in PLS-SEM are more significant than 0.50 , which means that every indicator has more contribution towards its construct. The outer loadings which were below 0.50 were removed (CC1, IP1, IP5, IP9) from the constructs due to their less contribution.

Table 8. Showing Construct Outer Loadings

\begin{tabular}{|c|c|c|c|c|c|}
\hline Constructs & Items & Loadings & Constructs & Items & Loadings \\
\hline & CC2 & 0.951 & & OA2 & 0.959 \\
\hline & CC3 & 0.834 & & OA3 & 0.973 \\
\hline & $\mathrm{CC} 4$ & 0.929 & & OA4 & 0.929 \\
\hline \multirow[t]{9}{*}{ Course Content } & CC5 & 0.841 & & OA5 & 0.959 \\
\hline & CC6 & 0.955 & Quality Instructors & Q11 & 0.968 \\
\hline & $\mathrm{CC} 7$ & 0.918 & & Q12 & 0.945 \\
\hline & CC8 & 0.946 & & Q13 & 0.931 \\
\hline & IP2 & 0.865 & & Q14 & 0.939 \\
\hline & IP3 & 0.824 & & Q15 & 0.939 \\
\hline & IP4 & 0.916 & User Interface & UI1 & 0.916 \\
\hline & IP6 & 0.911 & & UI2 & 0.980 \\
\hline & IP7 & 0.904 & & UI3 & 0.879 \\
\hline \multirow[t]{6}{*}{ Interaction with Peers } & IP8 & 0.921 & & UI4 & 0.975 \\
\hline & IP10 & 0.930 & Student Satisfaction & SAT1 & 0.968 \\
\hline & IP11 & 0.951 & & SAT & 0.974 \\
\hline & IP12 & 0.921 & & SAT & 0.896 \\
\hline & IP13 & 0.890 & & SAT & 0.966 \\
\hline & IP14 & 0.969 & & SAT & 0.962 \\
\hline Online Assignments & OA1 & 0.934 & & SAT & 0.960 \\
\hline
\end{tabular}

Source: developed by the authors.

Conclusions. This current study has provided several insights into online program offerings in the global era. Results and analysis revealed the relationship among constructs, but still, there are many aspects of other aspects multicollinearity issues, predictive relevance, and effect sizes that also need to be assessed. The following findings and managerial implications can be drawn. The purpose of this study is how the only one program quality can be improved from both business point of view as well as for understanding student's expectation from an online program irrespective of one's interest.

1. Several factors influence student satisfaction as the researcher has taken into this study, but the students are found to be more concerned with the user-friendliness of an interface instead of course content.

2. Meanwhile, it has also been found that Online Assignments also play a crucial role in the respondents who participated in this study.

3. Online program quality Perception is a multifaceted dimension, and it also involves quality instructors who also seen as a significant construct.

4. Content of course, although assumed to be essential along with the online discussion on forums here found not significant, which is an important finding also.

Since the present research was done on less sample size, it is suggested to replicate the same study using more sample and diversified data to establish a more concrete outcome of the study.

Author Contributions: conceptualisation, A.N., T. S.; methodology, A. N.; validation, A. N..; resources, RS; data curation, R. S.; writing-original draft preparation, R. S.; writing review and editing, A. N., T. S.; visualisation, R. S.; supervision, A. N.; project administration, A. N.,T. S, R. S. 
A., Nazneen, T., Alsulimani, R., Sharma. Marketing and Management in Higher Education: the Relationship between the Quality of Online Programmes and Student's Satisfaction.

\section{References}

Akter, S., D'Ambra, J. \& Ray, P. (2011). Trustworthiness in mHealth information services: an assessment of a hierarchical model with mediating and moderating effects using partial least squares (PLS). Journal of the American Society for Information Science and Technology, 62(1), 100-116. [Google Scholar] [CrossRef]

Allen, I. E., \& Seaman, J. (2010). Learning on demand: Online education in the United States, 2009. Sloan Consortium. PO Box 1238 Newburyport, MA 01950. [Google Scholar]

Al-Rahmi, W. M, Alias, N., Othman, M. S., Alzahrani, A. I., Alfarraj, O, Saged, A. A \& Rahman, N. S. A. (2018). Use of e-learning by University students in Malaysian higher educational institutions: a case in Universiti Teknologi Malaysia. IEEEAccess, 6,14268-14276. [Google Scholar] [CrossRef]

Anderson, J. C. \& Gerbing, D. W. (1988). Structural equation modeling in practice: A review and recommended two-step approach. Psychological Bulletin, 103(3), 411. [Google Scholar]

Bandura, A., Freeman, W. H., \& Lightsey, R. (1999). Self-efficacy: The exercise of control. [Google Scholar] [CrossRef]

Beyth-Marom, R., Saporta, K., \& Caspi, A. (2005). Synchronous vs. asynchronous tutorials: Factors affecting students' preferences and choices. Journal of Research on Technology in Education, 37(3), 245-262. [Google Scholar] [CrossRef]

Bhatti, N, Bouch, A., \& Kuchinsky, A. (2000). Integrating user-perceived quality into web server design. Computer Networks 33, (1-6),116. [Google Scholar] [CrossRef]

Boud, D. (1995). Enhancing leaming through self-assessment. Routledge. [Google Scholar]

Bouilheres, F., McDonald, S., Nkhoma, C., \&Jandug- Montera, L. (2020). Defining student learning experience through blended learning Education and Information Technologies, 1-21. [Google Scholar] [CrossRef]

Chao, I. T., Saj, T., \& Hamilton, D. (2010). Using collaborative course development to achieve online course quality standards. The Intermational Review of Research in Open and Distributed Leaming, 11(3), 106-126. [Google Scholar] [CrossRef]

CHEA. (2002). Accreditation and Assuring Quality in Distance Learning. CHEA Monograph Series 2002, Volume 1. Retrieved from https://www.chea.org/accreditation-and-assuring-quality-distance-learning

Chiu, C. M., Hsu, M. H., Sun, S. Y., Lin, T. C., \& Sun, P. C. (2005). Usability, quality, value and e-learning continuance decisions Computers \& Education, 45(4), 399-416. [Google Scholar] [CrossRef]

Dabbagh, N., \& Kitsantas, A. (2012). Personal learning environments, social media, and self-regulated learning: A natural formula for connecting formal and informal learning. The Intermet and higher education, 15(1), 3-8. [Google Scholar] [CrossRef]

Delone, W. H., \& McLean, E. R. (2003). The Delone and McLean model of information systems success: a ten-year update. Journal of Management Information Systems 19(4), 9-30. [Google Scholar] [CrossRef]

Diamond, R. M. (2011). Designing and assessing courses and curricula: A practical guide. John Wiley \& Sons. [Google Scholar]

Ensher, E. A., Heun, C., \& Blanchard, A. (2003). Online mentoring and computer-mediated communication: New directions in research. Journal of Vocational Behavior, 63, 264-288. [Google Scholar] [CrossRef]

Farhan, W., Razmak, J., Demers, S., \& Laflamme, S. (2019). E-learning systems versus instructional communication tools: Developing and testing a new e-learning user interface from the perspectives of teachers and students. Technology in Society, 59, 101192. [Google Scholar] [CrossRef]

Fein, A. D., \& Logan, M. C. (2003). Preparing instructors for online instruction. New Directions for Adult and Continuing Education, 100, 45-55. [Google Scholarl [CrossRef

Fife, J. D. (1988). Cognitive process in critical thinking. ASHE-Higher Education Report 17(2), 25-49. Retrieved from https://onlinelibrary.wiley.com/doilabs/10.1002/aehe.3640170207

Fornell, C. \& Larcker, D. F. (1981). Evaluating structural equation models with unobservable variables and measurement error. Joumal of Marketing Research, 18(1), 39-50. [Google Scholar] [CrossRef] Scholar]

Greenagel, F. L. (2002). The illusion of e-learning: why we're missing out on the promise of technology. On line learning, 4. [Google

Hair, J. F., Black, W. C., Babin, B. J., Anderson, R. E., \& Tatham, R. L. (1998). Multivariate data analysis (Vol. 5, No. 3, pp. 207-219). Upper Saddle River, NJ: Prentice hall. [Google Scholar]

Hair, J. F., Ringle, C. M. \& Sarstedt, M. (2011). PLS-SEM: Indeed, a silver bullet. Joumal of Marketing Theory and Practice, 19(2), 139152. [Google Scholar] [CrossRef]

Henseler, J., Ringle, C. M., \& Sinkovics, R. R. (2009). The use of partial least squares path modeling in international marketing. In New challenges to international marketing. Emerald Group Publishing Limited. [Google Scholar] [CrossRef]

Hew, K. F., \& Cheung. W. S. (2011). Higher-level knowledge construction in asynchronous online discussions: An analysis of group size,

duration of online discussion, and student facilitation techniques. Instructional Science, 39, 303-319. [Google Scholar] [CrossRef]. Hrastinski, S. (2009). A theory of online learning as online participation. Computers \& Education, 52, 78-82. [Google Scholar] [CrossRef]. Hu, L. T., \& Bentler, P. M. (1999). Cutoff criteria for fit indexes in covariance structure analysis: Conventional criteria versus new alternatives. Structural Equation Modeling: a multidisciplinary journal, 6(1), 1-55. [Google Scholar] [CrossRef] Ives, B, Olson, M. H., \& Baroudi, J. J. (1983). the measurement of user satisfaction. Communications of the ACM 26(10), 785-793. [Google Scholar] [CrossRef]

Kintu , M. J., Zhu, C., \& Kagambe, E. (2017). Blended learning effectiveness: the relationship between student characteristics, design features and outcomes. International Journal of Educational Technology in Higher Education, 14(1), 7.[Google Scholar] [CrossRef] 
A., Nazneen, T., Alsulimani, R., Sharma. Marketing and Management in Higher Education: the Relationship between the Quality of Online Programmes and Student's Satisfaction.

Kituyi, G., \& Tusubira, I. (2013). A framework for the integration of e-learning in higher education institutions in developing countries. International Journal of Education and Development using ICT, 9(2).[Google Scholar]

Lee, J. W. (2010). Online support service quality, online learning acceptance, and student satisfaction. The Internet and Higher Education, 13(4), 277-283. [Google Scholar] [CrossRef]

Lee, M. Y., Knight, D., \& Kim, Y. K. (2008). Brand analysis of a US global brand in comparison with domestic brands in Mexico, Korea, and Japan. Journal of product \& brand management.[Google Scholar] [CrossRef]

Li, C. S., \& Irby, B. (2008). An Overview of online education: Attractiveness, benefits, challenges, concerns, and recommendations. College Student Journal, 42(2), 449-458. [Google Scholar]

Limani, Y., Hajizi, E., Stapleton, L., \& Retkoceri, M. (2019). Digital Transformation Readiness in Higher Education Institutions (HEI): The Case of Kosovo. IFAC-PapersOnLine, 52(25), 52-57. [Google Scholar] [CrossRef]

Lin, B., \& Hsieh, C. T. (2001). Web-based teaching and learner control: A research review. Computers \& Education, 37(3-4), 377-386 [Google Scholar] [CrossRef]

Lucas Jr, H. C. (1978). Empirical model for a descriptive model of implementation. MIS Quarterly, 27-41. [Google Scholar] [CrossRef]

Luyt, I. (2013). Bridging spaces: Cross-cultural perspectives on promoting positive online learning experiences. Journal of Educational

Technology Systems, 42, 3-20. [Google Scholar] [CrossRef]

Lyons, J. F. (2004). Teaching US history online: Problems and prospects. The History Teacher, 37, 447-456. [Google Scholar] [CrossRef]

MacKinnon, D. P. (2008). Introduction to Statistical Mediation Analysis. Taylor and Francis group: New York. [CrossRef]

McLoughlin, C., \& Lee, M. J. (2010). Personalised and self-regulated learning in the Web 2.0 era: International exemplars of innovative pedagogy using social software. Australasian Journal of Educational Technology, 26(1), 28-43. [Google Scholar] [CrossRef]

McLoughlin, C., Brady, J., Lee, M.J. \& Russell, R. (2007). Peer-to-peer: An e-mentoring approach to facilitating reflection on professional experience for novice teachers. In Australian Association for Research in Education: AARE 2007. AARE. Retrieved from https://www.academia.edu/881624/Peer-to-peer An_e-

mentoring approach to developing community mutual engagement and professional identity for pre-service teachers

Moallem, M. (2003). An interactive online course: A collaborative design model. Educational Technology Research and Development, 51(4), 85-103. [Google Scholar] [CrossRef]

Nunnally, J. (1978). Psychometric Theory. New York: McGraw-Hill, 1978. Retrieved from http://garfield.library.upenn.edu/classics1979/A1979HZ31300001.pdf

Puzziferro, M. \& Shelton, K. (2014). A model for developing high quality online courses: Integrating a systems approach with learning theory. Journal of Asynchronous Learning Networks, 12. [Google Scholar]

Reeves, T. C., Herrington, J., \& Oliver, R. (2004). A development research agenda for online collaborative learning. Educational Technology Research and Development, 52(4), 53-65. [Google Scholar] [CrossRef]

Ringle, C. M., Wende, S., \& Will, A. (2005). SmartPLS 2.0 M3 Beta. [Google Scholar]

Robey, D. (1979). User attitudes and management information system use. Academy of Management Journal, 22(3), 527-538. [Google Scholar] [CrossRef]

Sekaran, U. \& Bougie, R. (2016). Research Methods for Business: A Skill Building Approach. UK: John Wiley and Sons. [Google Scholar] Shi, D. (2010). The Measurement of the CSI of e-learning courseware. In 2010 International Conference on E-Business and EGovernment (pp. 5586-5589). IEEE. [Google Scholar] [CrossRef]

Shu, H, \& Gu, X. (2018). Determining the differences between Online and face to face student group interactions in a blended learning course. The Internet and Higher Education , 39, 13-21. [Google Scholar] [CrossRef]

Smaldino, S. E. \& Yamagata-Lynch, L. (2015). The course-in-a-box: Design issues. TechTrends, 59(4), 71-78. [Google Scholar] [CrossRef]

Teo, T. (2010). A Path analysis of pre-service teachers' attitudes to computer use: applying and extending the technology acceptance model in an educational context. Interactive Learning Environments, 18(1), 65-79. [Google Scholar] [CrossRef]

Thorndike, R. M. (1995). Psychometric Theory (3rd ed.) by Jum Nunnally and Ira Bernstein New York: McGraw-Hill. [CrossRef

Tinto, V. (1999). Taking retention seriously: Rethinking the first year of college. NACADA Journal, 19(2), 5-9. [Google Scholar]

Voogt, J., Laferrière, T., Breuleux, A., Itow, R. C., Hickey, D. T., \& McKenney, S. (2015). Collaborative design as a form of professional development. Instructional Science, 43(2), 259-282. [Google Scholarl [CrossRef]

Wagner, N., Hassanein, K., \& Head, M. (2008). Who is responsible for e-learning success in higher education? A stakeholders' analysis. Journal of Educational Technology \& Society, 11(3), 26-36. [Google Scholar]

Xu, D., Huang, W. W., Wang, H., \& Heales, J. (2014). Enhancing e-learning effectiveness using an intelligent agent-supported personalised virtual learning environment: An Empirical investigation. Information \& Management, 51(4), 430440. [Google Scholar] [CrossRef Xu, H., \& Morris, L. V. (2007). Collaborative course development for online courses. Innovation in Higher Education, 32, 35-47. [Google Scholar] [CrossRef]

Zhai, X., Gu, J., Liu, H., Liang, J. C., \& Tsai, C. C. (2017). An experiential learning perspective on students' satisfaction model in a flipped classroom context. Journal of Educational Technology \& Society, 20(1), 198-210 [Google Scholar]

Zhang, D., Zhou, L., \& Briggs, R. O. (2006). Instructional video in e-learning: Assessing the impact of interactive video on learning effectiveness. Information \& Management, 43, 15-27. [Google Scholar] [CrossRef] 
A., Nazneen, T., Alsulimani, R., Sharma. Marketing and Management in Higher Education: the Relationship between the Quality of Online Programmes and Student's Satisfaction.

\author{
Афроз Назнеен, \\ Університет короля Абдельазіз, Саудівська Аравія \\ Тагреід Альсулімані, \\ Університет короля Абдельазіз, Саудівська Аравія \\ Рохан Шарма, \\ Інститут менеджменту і технологій Святого Солдієра, Індія
}

Маркетинг та менеджмент в системі вищої освіти: взаємозв'язок між якістю онлайн-навчання та рівнем задоволення студентів

Розвиток інформаційних технологій обумовлює поширення та зростання попиту на онлайн-навчання. Однією з переваг онлайн-навчання для закладів вищої освіти - це можливість залучення більшої кількості студентів; для студентів - гнучкий графрік навчання та індивідуальне планування навчального навантаження. Метою статті $є$ аналіз факторів, що впливають на якість програм онлайн-навчання, рівень задоволеності та лояльності студентів, а також взаємозв'язок між визначеними фракторами. На основі систематизації наукових напрацювань щодо досліджуваної тематики, у статті виокремлено основні параметри якості програм онлайн-навчання: контент навчального курсу, інтерактивність завдань, взаємодія між студентами, компетентність викладача та інтерфейс користувача. Для перевірки висунутих гіпотез та емпіричного їх підтвердження використано метод найменших квадратів за допомогою програмного забезпечення Smart PLS. Детерміновану вибірку даних сформовано на основі результатів опитування 100 респондентів. На основі отриманих емпіричних результатів авторами побудовано модель структурних рівнянь, що описує силу впливу виокремлених латентних змінних та пояснює їх варіації взаємодії. Враховуючи отримані результати, встановлено, що сприйняття програм онлайн-навчання залежить від значної кількості факторів, одним із яких $є$ компетенції викладача. При цьому результати дослідження спростували әіпотезу про наявність статистично значущого впливу якості контенту онлайн-курсу на підвищення рівня задоволеності та лояльності студентів онлайннавчанням. Доведено, що якість, швидкість та доступ до Інтернету є вирішальними факторами поширення онлайннавчання серед студентів. Авторами наголошено, що заклади вищої освіти повинні підвищувати компетенції викладачів та якість програм онлайн-навчання, шляхом створення інтерактивних завдань та зручного інтерфейсу для студентів.

Ключові слова: онлайн-курс, задоволення студента, MOOCS, ефективність програми, компетентність викладача, вища освіта.

Manuscript received: 05.02.2020

(C) The author(s) 2020. This article is published with open access at Sumy State University. 